\title{
IS RUSSIAN DECOMMODIFYING IN CATALONIA?
}

\author{
Miquel Cabal-Guarro \\ Research Centre for Sociolinguistics and Communication (CUSC) \\ University of Barcelona \\ 585 Gran Via de les Corts Catalanes, 08007 Barcelona, Spain
}

\begin{abstract}
The data collected in an ethnographic study conducted between 2014 and 2016 in tourist areas in Catalonia, Spain shows that the mastery of Russian has become a profitable commodity in Spanish tourism industry. The purpose of this paper is to show where and how Russian is used in the service industry and trace the commodification of the language over time. Against the background of fluctuating numbers of Russian-speaking visitors, this analysis will contribute to a better understanding of processes of language commodification and decommodification and the relationship between wider political and economic contexts and valorisation of particular languages and speakers.
\end{abstract}

Keywords: Russian, commodification, linguistic landscapes, tourism, Catalonia, Spain

\section{INTRODUCTION}

Tourism is currently one of the largest and most dynamic sectors of the Catalan economy: in 2014 it contributed approximately 12\% of the Catalan GDP (Agència Catalana de Turisme, 2015). In the context of this ongoing influx of visitors, linguistic exchanges become symbolic exchanges of both cultural and social capital that, under certain conditions, can be converted into economic capital (Bourdieu 1986). What this means, in other words, is that languages function not only as a means of communication, but also as a way to add value to particular products and services. This double duty makes languages, in the view of Heller and associates (2014) "one of the key sites for a sociolinguistic study of the political economy of globalization" (563). The purpose of the present paper is to examine how a particular language — Russian — functions as a commodity in Catalonia's tourism industry within different moments in time.

Official data about tourism flows from countries of the former USSR show that Russian speakers visit Catalonia in large numbers: in 2013 alone nearly one million travellers from the Russian Federation visited this Spanish region (Figure 2). As a result, Russian soon became visible on the streets of Barcelona and other touristic and shopping spots along the Catalan coast, prompting us to conduct an ethnographic study of the actual role of Russian and Russian-speaking tourism workers in the Catalan economy.

In what follows, I will begin with some theoretical considerations, followed by information on Russian tourism in Spain and the design of our study. Next, I will compare the data collected in 2014 with the 2016 data and try to draw some general conclusions about ways in which Russian gained and then lost (some of) its commercial value. 


\section{SOME THEORETICAL CONSIDERATIONS}

While global mobility and tourism in particular are not new phenomena per se, the onset of the global new economy now allows for commodification of virtually anything (Appadurai 1986). Within this context, tourism emerges as an insightful terrain in the study of language commodification being characterized by two distinct yet closely connected expressions that highlight the conversion of linguistic capital into economic one.

"Tourism presents itself as a means to navigate the new economy in ways which allow for the commodification of culture, identity and language, on the one hand, and the exploitation of multilingual communication skills, on the other. Exactly how this happens is different from one case to another, depending for example, on the nature and degree of economic crisis, access to resources of interested actors, the extent of existing tourism infrastructure or specific local sociohistorical conditions. What they have in common is the fact that this new field of practice produces specific configurations of the interrelation between the symbolic and the economic [...]" (Heller et al. 2015: 563).

First, however, it is necessary to establish what I understand by the term commodity and by the notion of language commodification. According to Heller et al. (2014: 545), "commodification is the expression we use to describe how a specific object or process is rendered available for conventional exchange in the market". Undoubtedly, there is something uncomfortable in this approach to language skills and language work as a commodity exchangeable for money in the capitalist economy. However, linkages and interconnections between language, speakers and the economy within current politicaleconomic conditions are well-described phenomena (Heller 2003; Heller and Duchêne 2012; Irvine 1989), prompting us to further study the conditions that make particular languages and speakers more 'valuable' than others and ask, in which specific contexts this takes place. Thus, for this research on the commodification of Russian within the Catalan tourism industry I have adopted the approach by Pavlenko (2017) that, following Heller (2010) defines commodification of Russian as,

"[...] the process where a new value is accorded to linguistic resources and is made commensurable across a set of exchangeable things. Exchangeable things refer to salaries and other forms of financial compensation received by speakers of Russian in functioning markets in expectation of greater profits. The resources involve Russian as a technical skill [...]" (2).

Taking this notion of commodification of languages and speakers as the point of departure, I will now discuss the context of our research, namely Russian tourism in Spain and Catalonia.

\section{RUSSIAN TOURISM IN CATALONIA}

According to the last reports of the World Economic Forum (WEF 2015) and the United Nations World Travel Organization (UNWTO 2014), Spain's tourist appeal comes mainly from its extremely competitive tourist service infrastructure, its heritage sites and its cultural resources, as well as from the good safety, security, health 
and hygiene conditions. All these elements are combined with almost eight months per year of good weather and the relatively moderate price of all major services and consumer products.

Russian tourism first began to grow in the early 2000s, but the increase in the numbers of Russian visitors in Europe became more dramatic and noticeable by 2009 (Pavlenko 2017). Both in absolute and relative figures, the amount of Russian tourists in Spain increased consistently until 2013. According to Russian Tourism Bureau, in 2009, almost 370.000 Russians travelled to Spain and by 2013 the number of tourists visiting the country rose to 1.275 .000 . That represents a $300 \%$ increase in a mere fiveyear period (see Figure 1). Furthermore, these statistics capture only Russian visitors from Russia, yet Russian-speaking tourists also come to Spain from other post-Soviet countries, as well as from Russian diasporas in Germany and Israel. However, since 2014 and the onset of the political crisis in Ukraine, the annexation of Crimea and the economic sanctions imposed by the European Union and the United States, tourist visits to both Spain and Catalonia decreased (Figures 1 and 2). This trend was further accelerated by falling revenues from the export of the country's natural resources and the subsequent devaluation of the Russian Rouble.

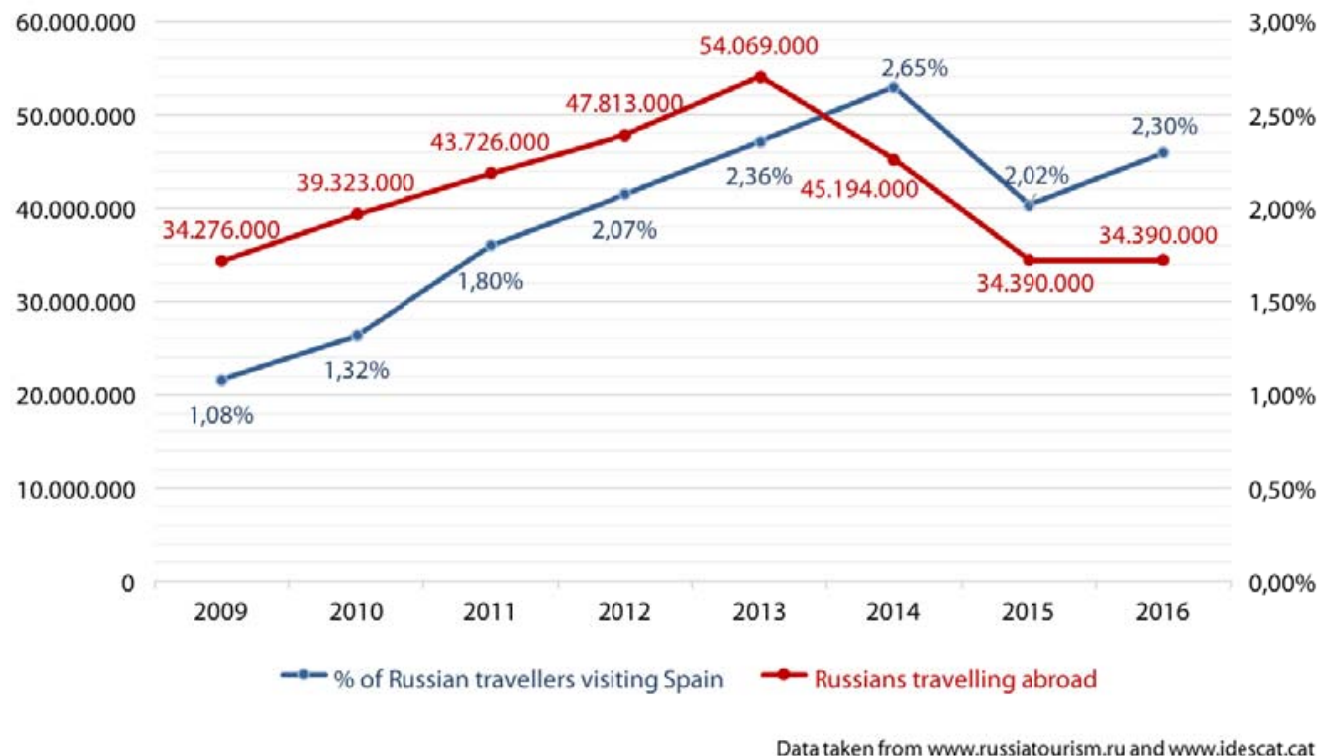

Figure 1. Overall number of Russian tourist visits abroad and percentage of Russian travellers visiting Spain (2009-2016)

Importantly, 70 to $80 \%$ of all Russian visitors in Spain pick Catalonia as their holiday destination (figure 1). Besides all the factors mentioned above regarding Spain's appeal to tourism, Catalonia is a notable international transport hub, with direct connexions to all major world airports. Moreover, Catalonia (and especially Barcelona) has an excellent and diverse hotel infrastructure, as well as an overwhelming concentration of heritage, cultural and shopping sites. 


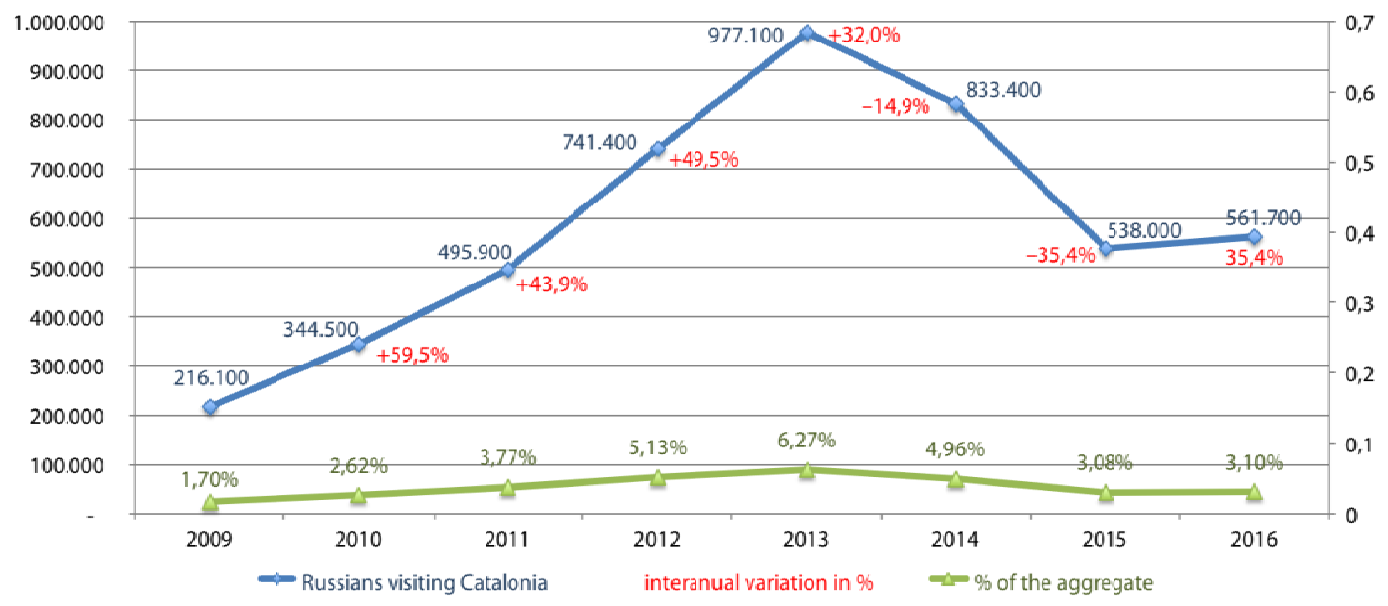

Data taken from www.idescat.cat

Figure 2. Number of Russians visiting Catalonia and overall share of Russian visitors (2009-2016)

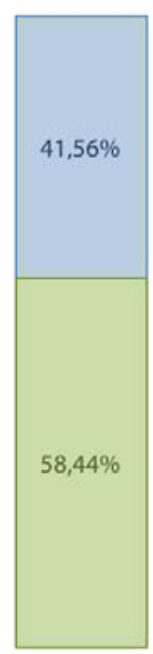

2009

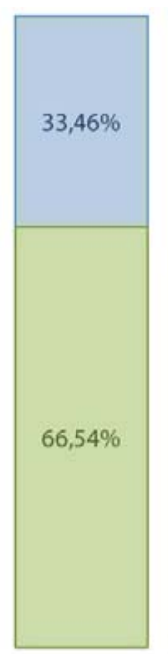

2010

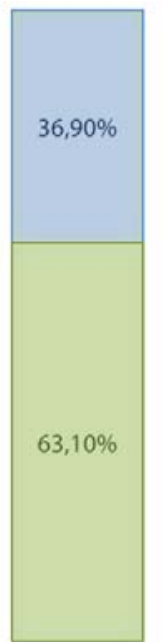

2011

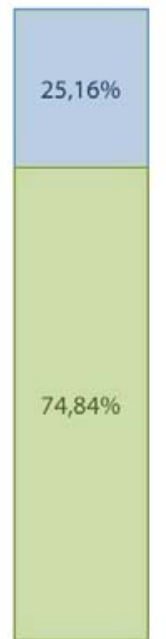

2012

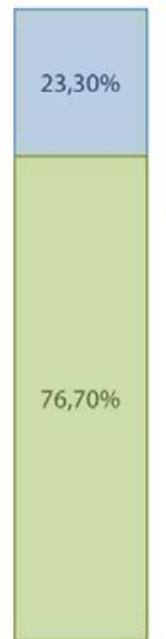

2013

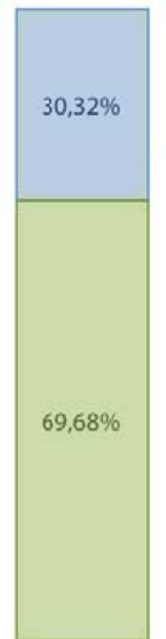

2014

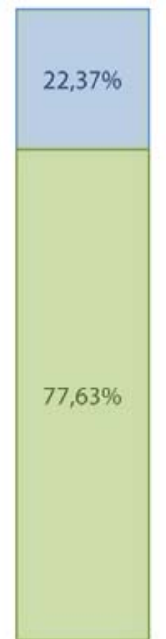

2015

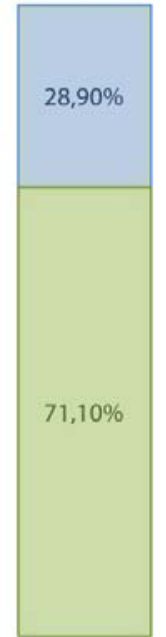

2016

$\square$ Russians travelling to the rest of Spain

Russians travelling to Catalonia

Data taken from www.russiatourism.ru and www.idescat.cat

Figure 3. Comparison of Russian visitor numbers to Catalonia and Spain (2009-2016)

The number of Russian visitors in Catalonia has been changing in changed in the same manner as in the rest of Spain, rising from 2009 to 2013 and dramatically falling from 2014 onward. In 2013, with almost a million of visitors, Russians represented more than $6 \%$ of foreign tourists in Catalonia.

In Catalonia, visitors from Russia rank fifth in terms of daily expenditures with an average of $177 €$ per person, only after tourists coming from the Arabian Gulf region, the USA, the rest of America and Scandinavian countries (www.idescat.cat). That being said, there is no doubt that this contingent of Russian tourists had and still has an impact in all the fields related to the tourism industry. In order to understand this impact, 
I analyse the presence and importance of the Russian language in different domains linked to tourism, namely hospitality (restaurants, bars and hotels), retail, real estate, and the language industry.

\section{METHODOLOGY}

In May 2014 I conducted 218 interviews in shops, bars and restaurants in central Barcelona and in Salou, a coastal resort near Tarragona. In Barcelona, data was collected in the shops, bars and restaurants of Passeig de Gràcia (54\% of the interviews), Portaferrissa street (17\%) and Portal de l'Àngel street (17\%). In Salou, the data was collected on the main shopping street of Salou with $12 \%$ of overall interviews). In addition to these short interviews, in 2015 I held six in-depth conversations with hotel staff managers and real estate agents in Salou and Cadaqués, a coastal resort along the Costa Brava. Our goal was to obtain more comprehensive information about the value of Russian in different commercial fields and in different localities popular with Russian visitors. In addition I collected data from chambers of commerce, real estate agencies, and language school and took pictures of linguistic landscapes (Shohamy and Gorter 2008). Linguistic landscaping as a methodology within sociolinguistic research refers to the study of language in the public sphere of mostly urban environments. In this research, linguistic landscaping has the advantage to provide data on the use of Russian (also in relation to other languages) on shop fronts, posters, advertising banners and billboards, but also on restaurant menus, leaflets and within stores and restaurants. Furthermore, it allows for the documentation of language use over time (Pavlenko and Mullen, 2015), an aspect that will provide helpful for scholars wishing to revisit particular locations and document, how and to what extent written language use has changed over time in a given area, in turn relating those to wider political and economic contexts.

The choice of the specific research sites was conditioned by several reasons. In the case of Barcelona, the typological disparity of the shopping streets results from the traditional commercial organisation of the city around trade unions, roughly following the principle one street, one business activity), as well as from the current gentrification processes which have extraordinarily altered the city centre in recent years. Passeig de Gràcia is an upmarket spot; it is extremely exclusive in its upper side, with international haute couture brands and becoming more oriented towards middle-class customers near Portal de l'Àngel. Portal de l'Àngel itself is a traditional shopping street, home to one of the first department stores in Barcelona. At present, it is a middle-class oriented shopping street, with all major franchise stores you can find in shopping centres all over the world, as well as with some traditional shops that still resist the severe gentrification taking place in the area. In fact, Portal de l'Àngel happens to feature the most expensive real estate in Spain concerning retail stores, with Passeig de Gràcia ranking third on the same list (Cushman and Wakefield 2016). Finally, Portaferrissa is a traditional commercial street, with shops and bars ranging from middle-class oriented to very popular.

The tourist spots by the sea were chosen for similar reasons. Salou is a very popular beach spot in Costa Daurada with non-expensive hotels and services, easily accessible from Barcelona by train and by a low-cost airport in nearby Reus. On the other hand, Cadaqués is an exclusive spot along the Costa Brava, accessible only after a long and winding drive. It is a small village with about 3.000 inhabitants and that has preserved 
its appearance as an old fishing town, hosting the unique and attractive Salvador Dalí House Museum. Moreover, it has a very restrictive policy regarding the development of real estate, making it almost impossible to build new houses in the village, resulting in exceptionally high prices for real estate. The breakdown of the surveyed establishments is as follows:

1. Clothes and shoes shops $(62 \%)$

2. Jewellery and watches shops $(5 \%)$

3. Restaurants and bars (18\%)

4. Household goods (5\%)

5. Souvenirs and gifts shops $(5 \%)$

6. Perfume shops $(5 \%)$

Since I was entering shops and bars during work hours without prior notification, my first intention was not to disturb anybody. To be as efficient as possible, without being intrusive, I designed a concise questionnaire that combined with notes and observations, could provide up to ten indicators for every establishment. The questionnaire consisted of the following questions:

1. Anyone of your staff speaks Russian? How many people?

2. Since when do you have Russian-speaking staff?

3. Is there any signage in Russian? Do you care if I take a picture?

4. Is there anything you want to say about Russian in Catalonia?

The analysis of the data I collected shows that in 2014 services in Russian were widely available in the upper-class-oriented shopping area of Passeig de Gràcia in Barcelona and in the tourist-oriented beach shopping area of Salou, whilst in all other areas it was less frequent. Altogether, Russian was spoken nearly in half of the surveyed commercial establishments, highlighting the potential exchange value of the language and confirming that entrepreneurs had decided to invest into the language at some point, most likely during the onset of mass tourism from Russia around 2010. As seen in Figure 4, the availability of Russian-speaking personnel was especially high in Passeig de Gràcia.

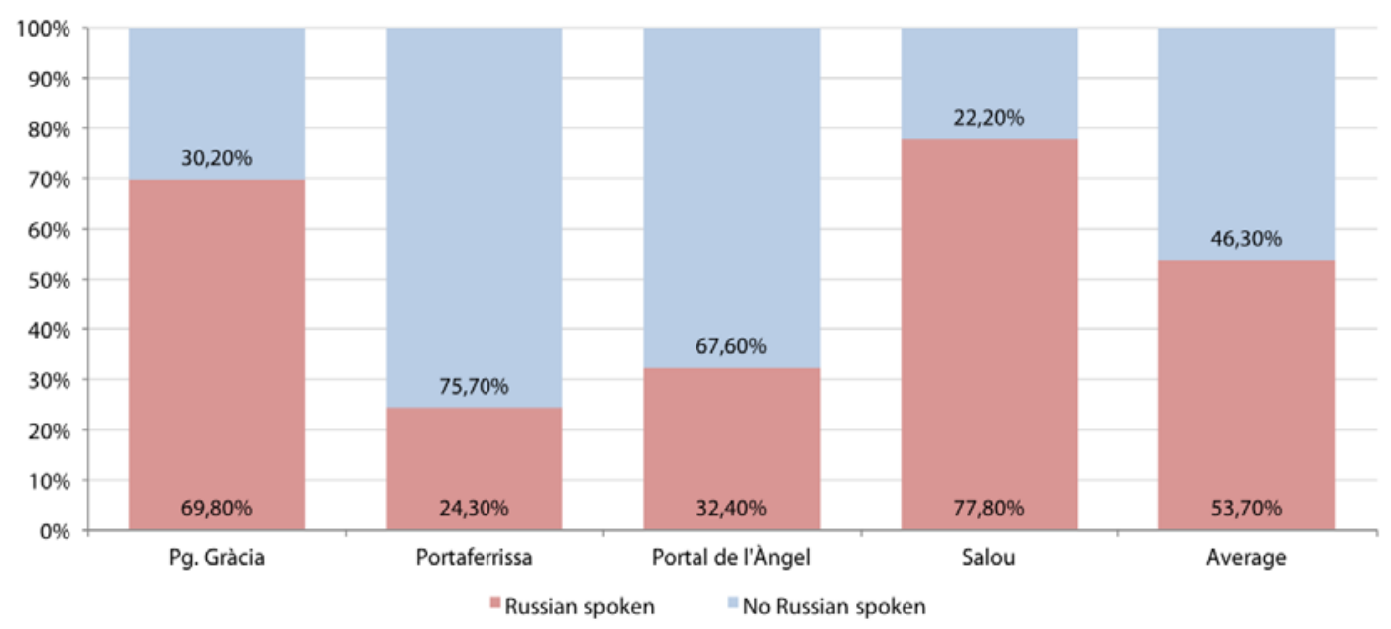

Figure 4. Number of enterprises with Russian-speaking customer service in the four areas of research 
Remarkably, in one international haute couture shop and in one jewellery shop along Passeig de Gràcia, all sales staff was either Russian or Russian-speaking. It's not easy to know who are the owners of these establishments, since they are usually operated by shell companies. In a number of jewellery shops, half of the staff was Russian-speaking and the other half was Chinese-speaking, hinting that Chinese is also a commodity in the local tourism industry (see Image 1).

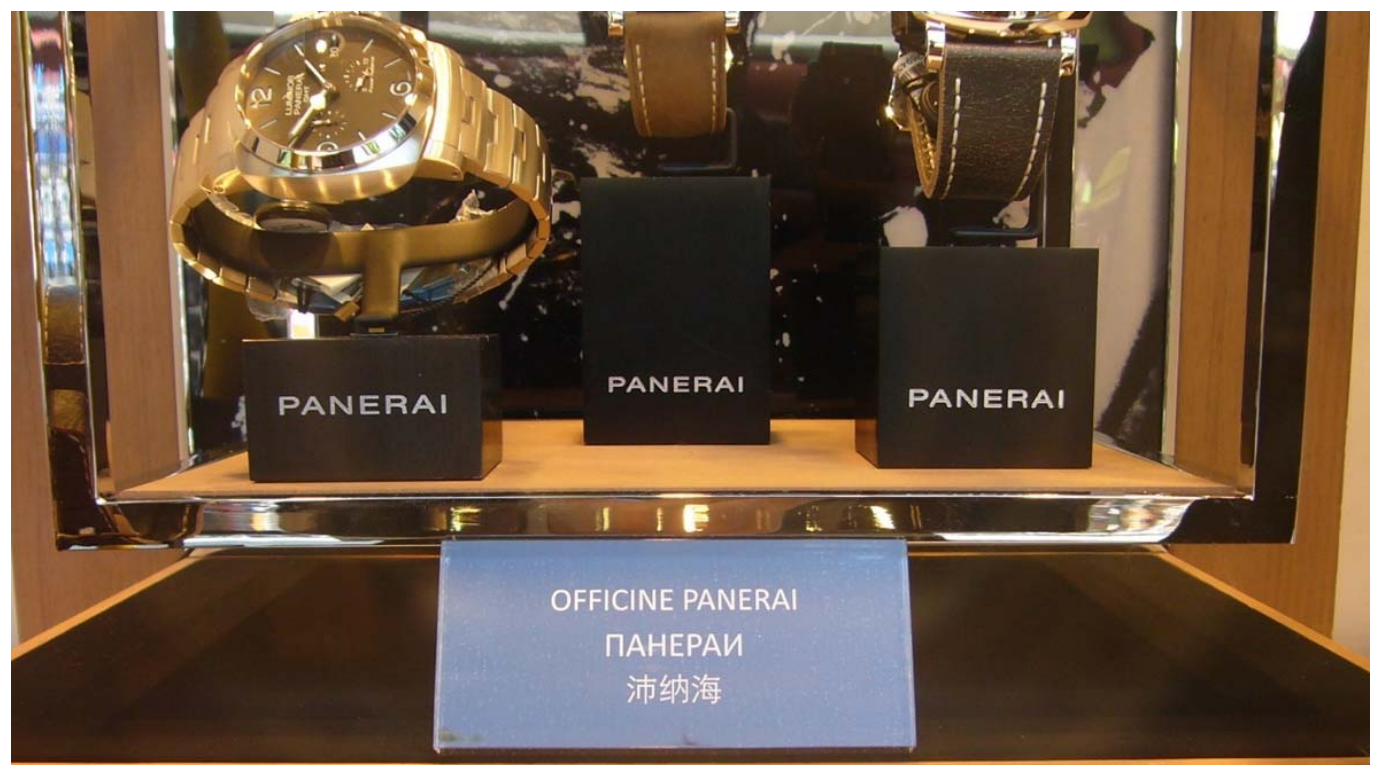

Image 1. Display in Russian and Chinese at a shop front of a jewellery shop

In Passeig de Gràcia and in Salou, shops featured Russian-speaking staff for almost four years during our initial research in 2014. The vast majority of these Russian speakers were Russian or Ukrainian nationals with legal residence in Catalonia; I found only four interviewees in Barcelona and five in Salou who were Catalonians with an intermediate level of Russian. I do not know what languages were spoken in the establishments before, presumably French and German, which have been now replaced by an English-only policy towards every language except for Russian and Chinese, since Russian- and Chinese-speaking visitors usually don't have even an elementary command of any foreign language.

Figure 5 presents the results according to the type of establishment. I can see that luxury establishments were more prone to offer services in Russian, with the language being spoken in the vast majority of jewelleries and international haute couture shops (such as Versace, Vuitton, Chanel, etc.). Around half of the stores selling home goods with a slightly lower proportion of perfume shops - offered their service in Russian, while one third of the souvenir shops claimed to be able to offer their services to Russian speakers in Russian.

With regard to restaurants and bars, I found that $25 \%$ of the establishments offered service in Russian; in addition to that, $54 \%$ of the visited bars and restaurants had menus 
in Russian. According to a satisfaction survey conducted by a tourism operator in 2013, $50 \%$ of Russian tourists complained about poorly translated or non-existent menus and about the lack of attention in Russian in hotels and restaurants (DIBA/SERHS 2014). Here, Image 2 could serve as an example of what most likely is the result of an automated translation. The word for menu in Catalan and Spanish is carta, which happens to be also the word for letter. In the Russian version of this restaurant menu, the very word тепи (carta) has been translated as письмо, the Russian word for letter, instead of меню, the correct translation for menu that is, in fact, a loan of the French menu.

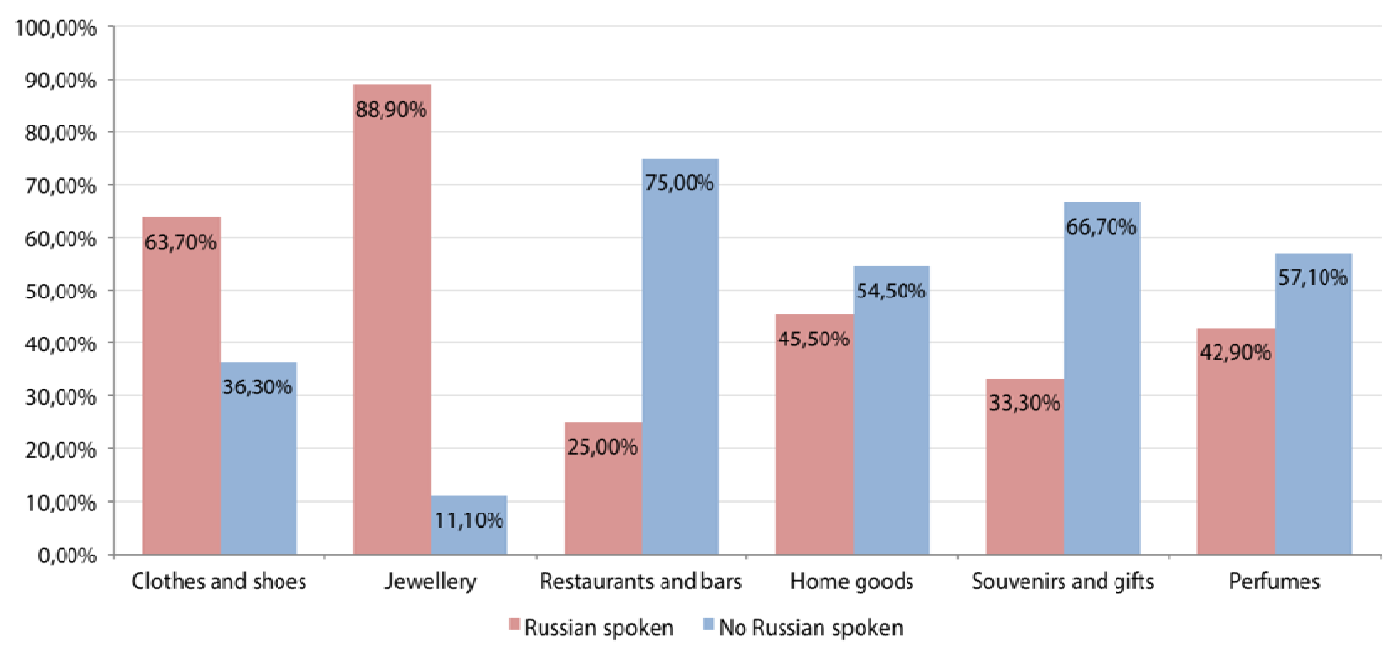

Figure 5. Percentage of services being available in Russian

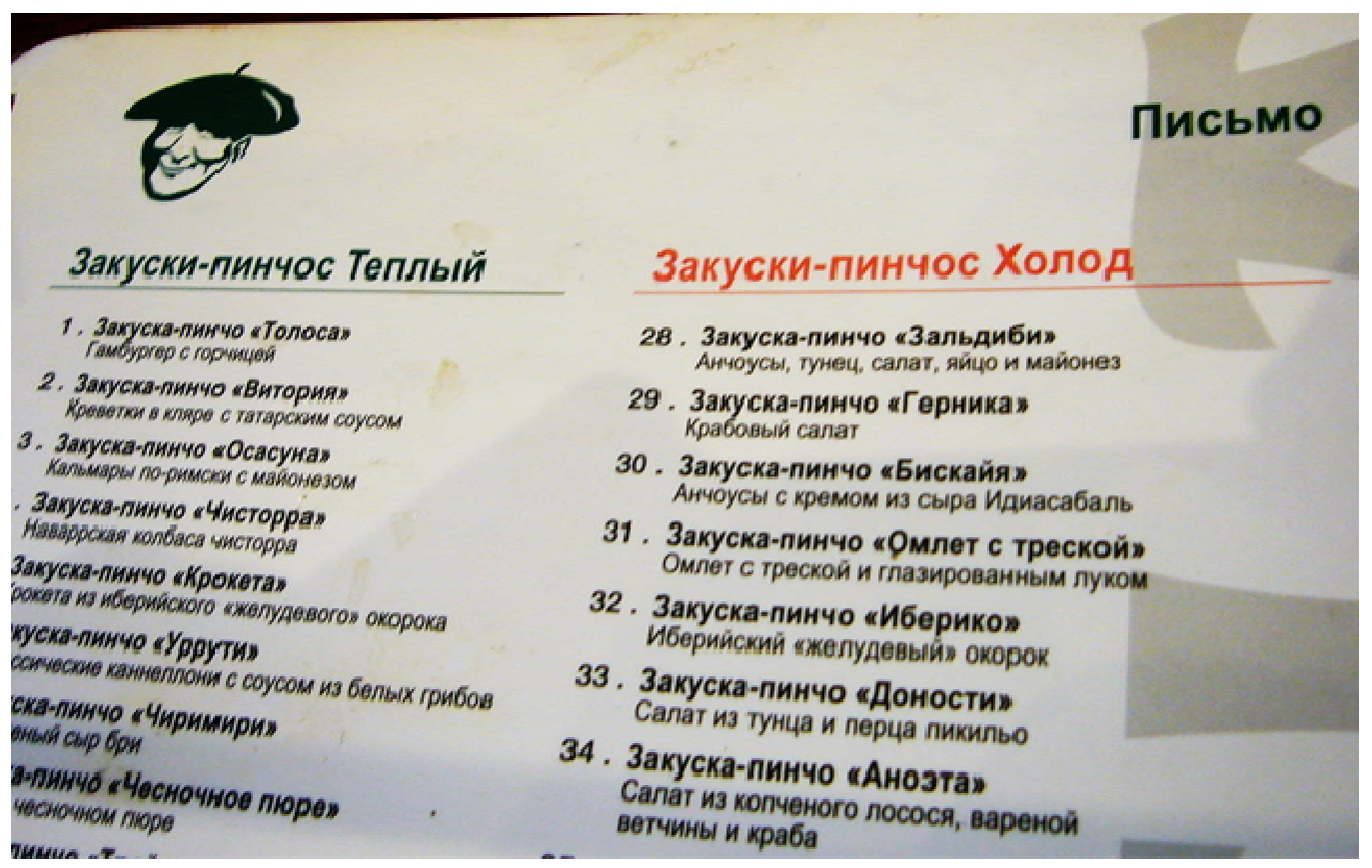

Image 2. Detail of a badly translated menu in a Barcelona restaurant 


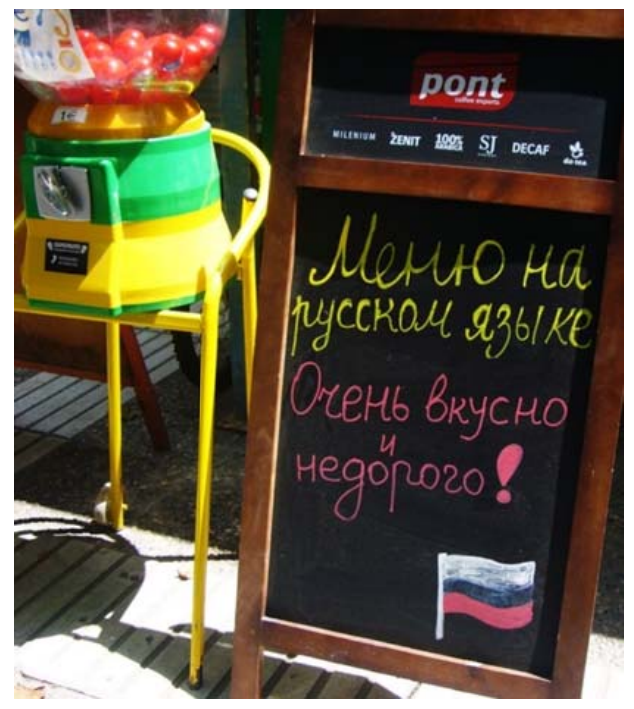

Image 3. Street sign in Barcelona: "Menu in Russian. Good and cheap food!"

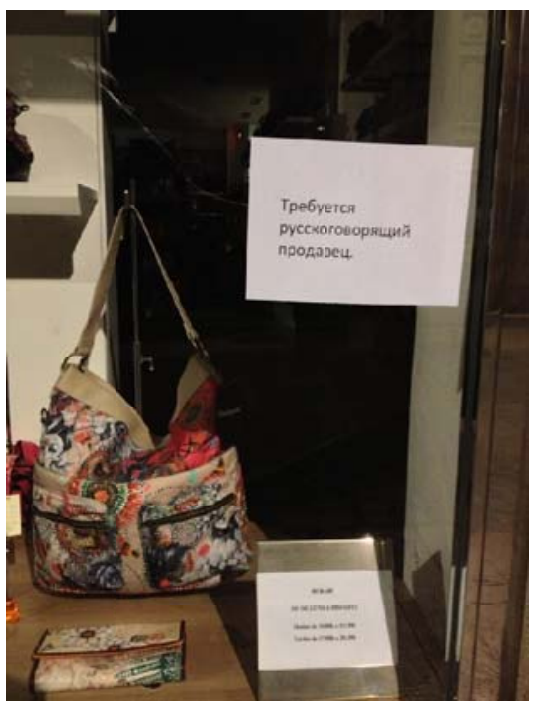

Image 4. Sign in a shop in Salou: "Russian-speaking sales person needed"

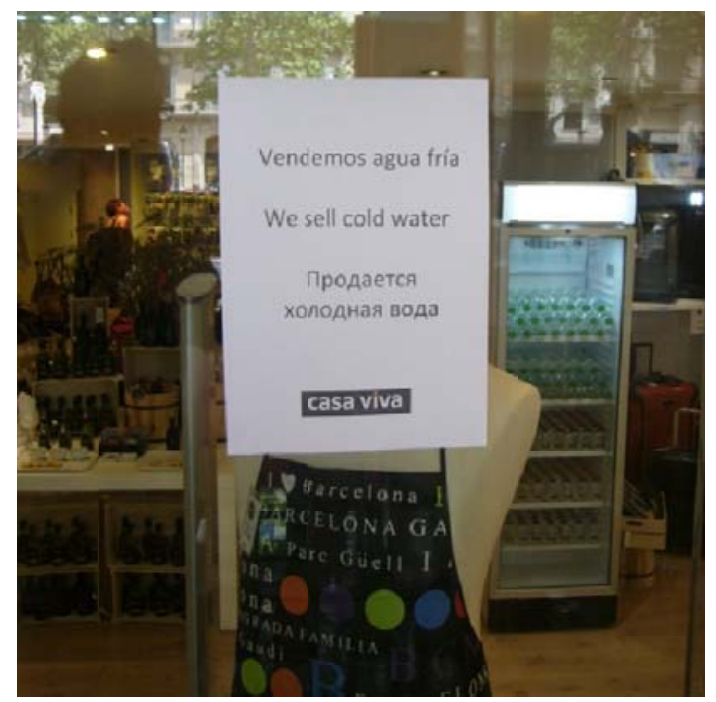

Image 5. Sign in a shop in Barcelona (Passeig de Gracia) in Spanish, English and Russian

In 2015, following the dramatic decrease in numbers of Russian speaking visitors, staff managers of three hotels in Salou and Barcelona told us that they were keeping their Russian-speaking personnel because Russians were still visiting Catalonia and had not been replaced by speakers of other languages that would require specific attention. At the same time, a staff manager of a hotel in Barcelona told us that after the high season they would lay off a Russian-speaking personal assistant and hire an Arabic-speaker from the Persian Gulf region with additional proficiency in English to perform the same job. In that specific hotel located in central Barcelona, affluent Russians were being replaced by equally affluent visitors from the Gulf. 


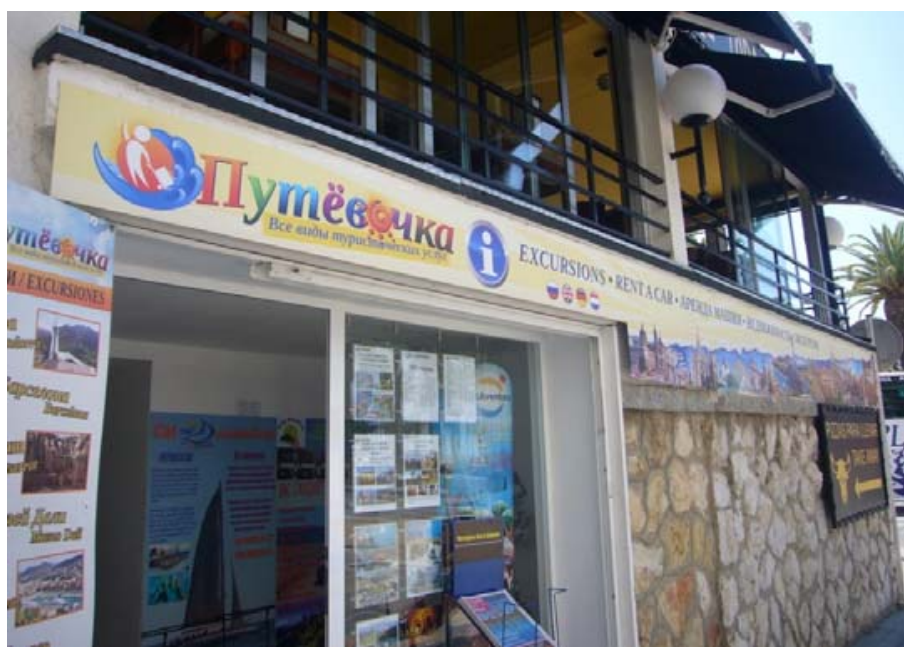

Image 6. Tourist services offered in Russian in Salou

\section{BEYOND CONVENTIONAL TOURISM: THE REAL ESTATE INDUSTRY}

We also took a look at the real estate industry, where Russians are among the top buyers. In 2016, Russians bought $2,83 \%$ of the houses purchased by foreigners in Spain, ranking $10^{\text {th }}$ in a list topped by UK nationals. In Catalonia, Russians bought $3,99 \%$ of houses purchased by foreign nationals and ranked $5^{\text {th }}$ in a list topped by Chinese nationals. If we compare the relative figures of the last three years, we'll see that the share of Russian-bought houses in Catalonia shows higher rates than the average in Spain (Figure 6).

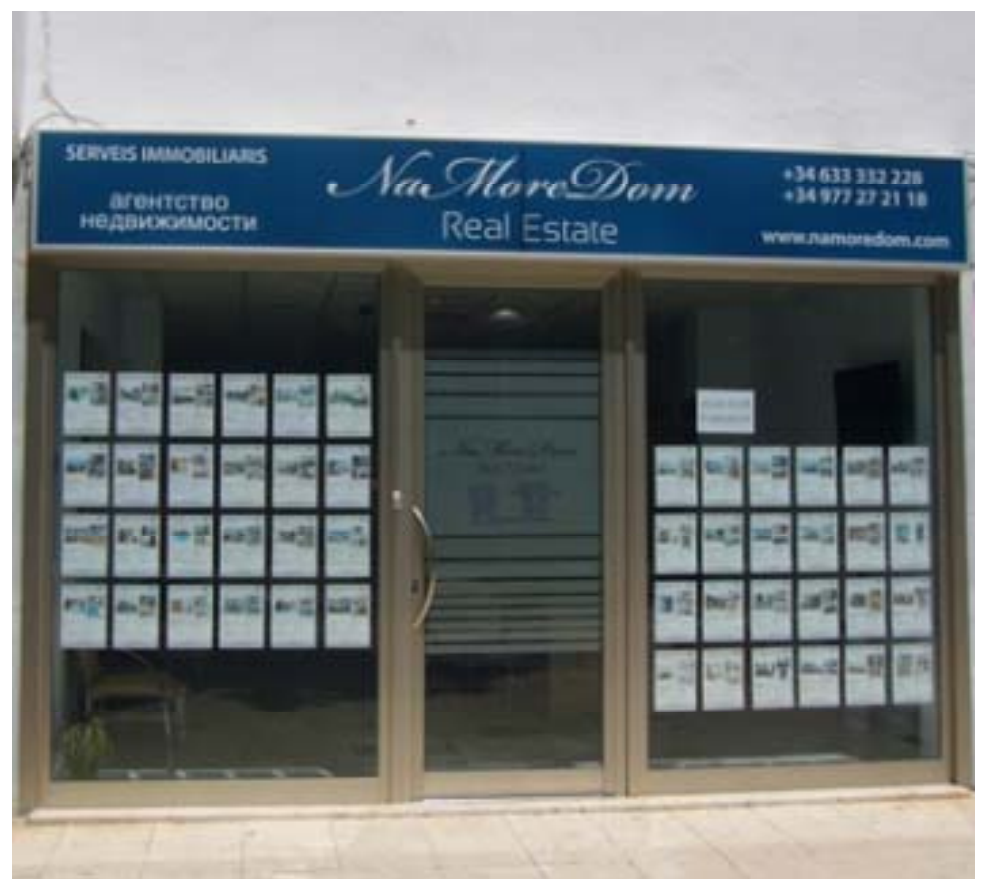

Image 7. Russian real estate agent in Salou 
Miquel Cabal-Guarro. Russian Journal of Linguistics, 2017, 21 (3), 605-619

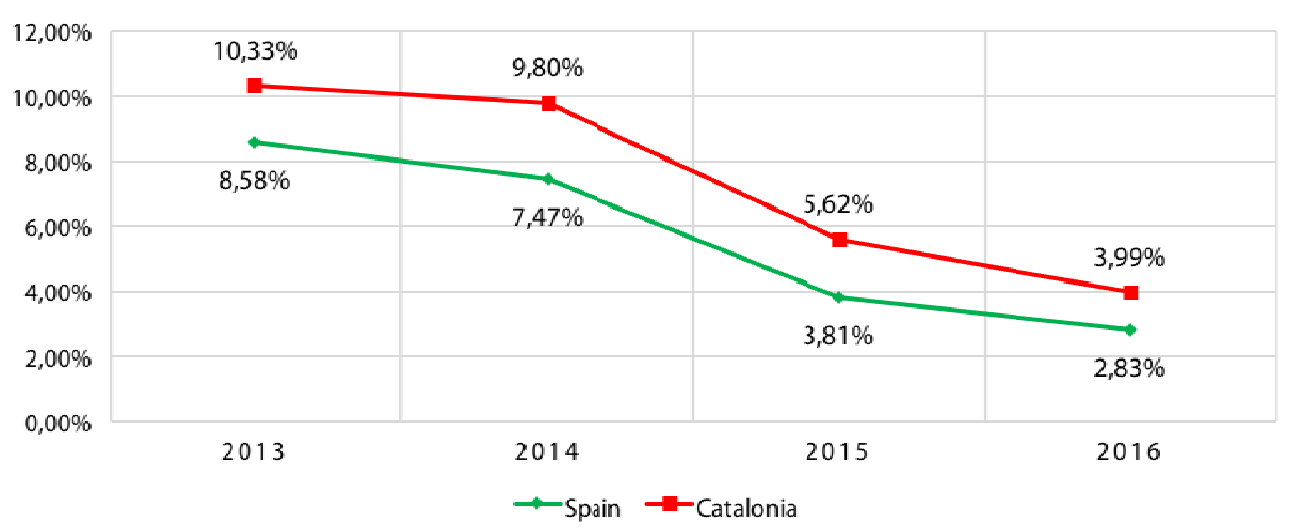

Figure 6. Share of Russians in the overall number of foreigners acquiring real estate in Spain and Catalonia (2013-2016)

In my research in 2014, I found out that 29 out of a total of 122 officially recognised real estate agents in north-eastern Catalonia (including the Costa Brava) either were Russians or spoke Russian (see Images 4 and 5). I have no up-to-date official information about this, but the decrease in the number of houses bought by Russians that, however, can also be attributed to market saturation, could be a sign pointing to a change in the value of Russian in the real estate market.

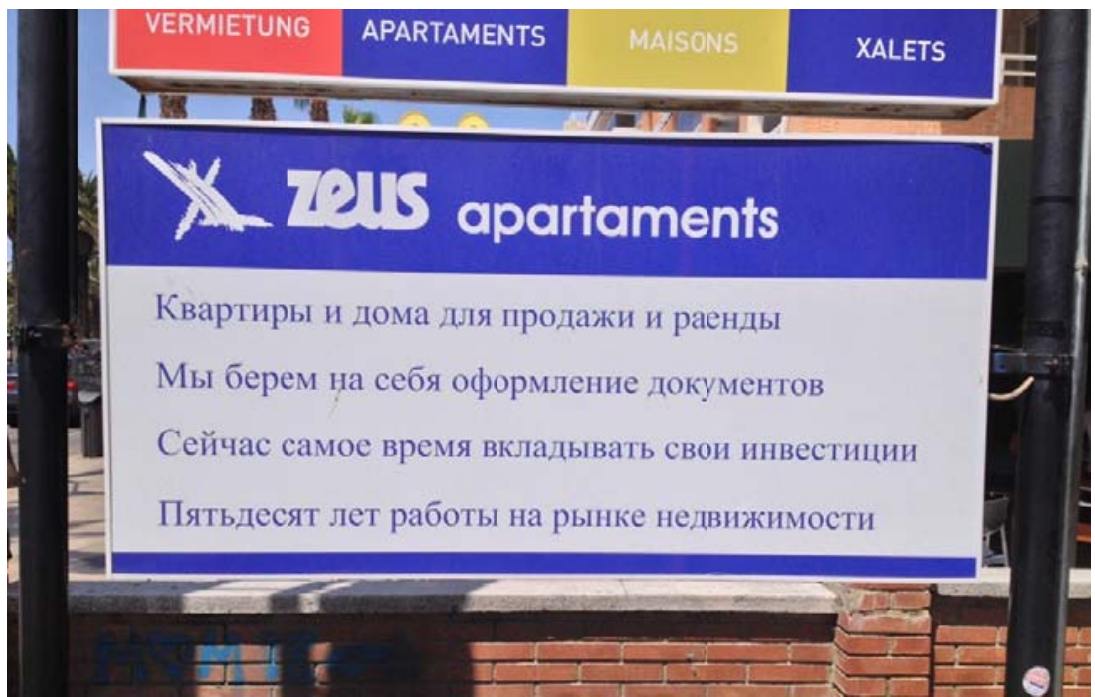

Image 8. Apartments and real estate services offered in Russian in Salou. There is a misspelled word which went all through the production process of the sign, probably managed by non-Russian-speakers

For instance, in 2011 there used to be a real estate agent in Cadaqués that operated under the name of 'Russia Cadaqués'. Altogether there are four real estate offices at work in the village and one of them was devoted to the Russian (or Russian-speaking) market. This agency closed in summer 2015; with no official data to evaluate, one could speculate that this closure is a sign of a more general trend of Russian losing some of its commodity value, at least within the real-estate industry. 


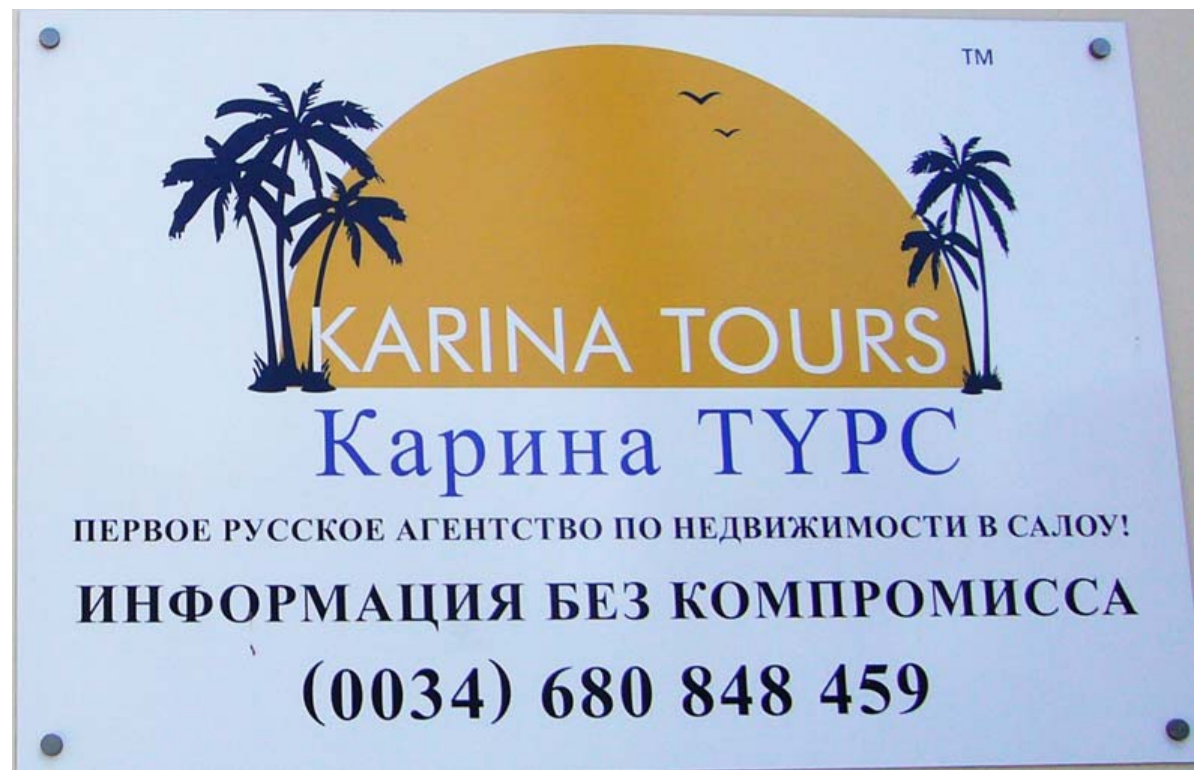

Image 9. Russian real estate agent in Salou. It claims to be the first Russian agent in town.

\section{LEARNING RUSSIAN}

The last domain I analyse in relation to the valorisation of Russian in Catalonia is the extent to which this language is learnt in official language schools. There is no data on private language courses, so I have to take the official data as the only indicator. There are 45 official language schools in Catalonia. Russian is learnt in 7 of them, namely in Barcelona, Calella, Girona, Lleida, Salou, Tarragona and Tortosa. In relation to the overall number of foreign language students, the number of those learning Russian did not significantly change in the past 15 years. In absolute figures, students have doubled in number if compared with pupils as of 1999-2000, but the total share is still under the $2 \%$ of overall language students (Figure 7 ).

In our opinion, the increase in the aggregate number of Russian learners has more to do with the widespread growth of foreign language learning across Europe than specifically with the Russian language itself. The subtle drop in $2014-15$ could be easily interpreted as a reflection of the mantra repeated in the media for almost three years, namely 'this is the end of the Russian tourism as we know it' . Besides these students learning Russian in language schools, official statistics (2013) suggest that there are 71.000 fluent speakers of Russian in Catalonia, including native (L1) and non-native advanced speakers.

\footnotetext{
${ }^{1} \mathrm{https}$ //themoscowtimes.com/articles/russian-outbound-tourism-suffers-sharpest-drop-since1998-52116

http://elpais.com/elpais/2015/10/22/inenglish/1445523527_884874.html

https://www.theguardian.com/world/2015/sep/04/wooing-the-russians-how-spain-and-italy-aretrying-to-lure-back-lost-tourists
} 


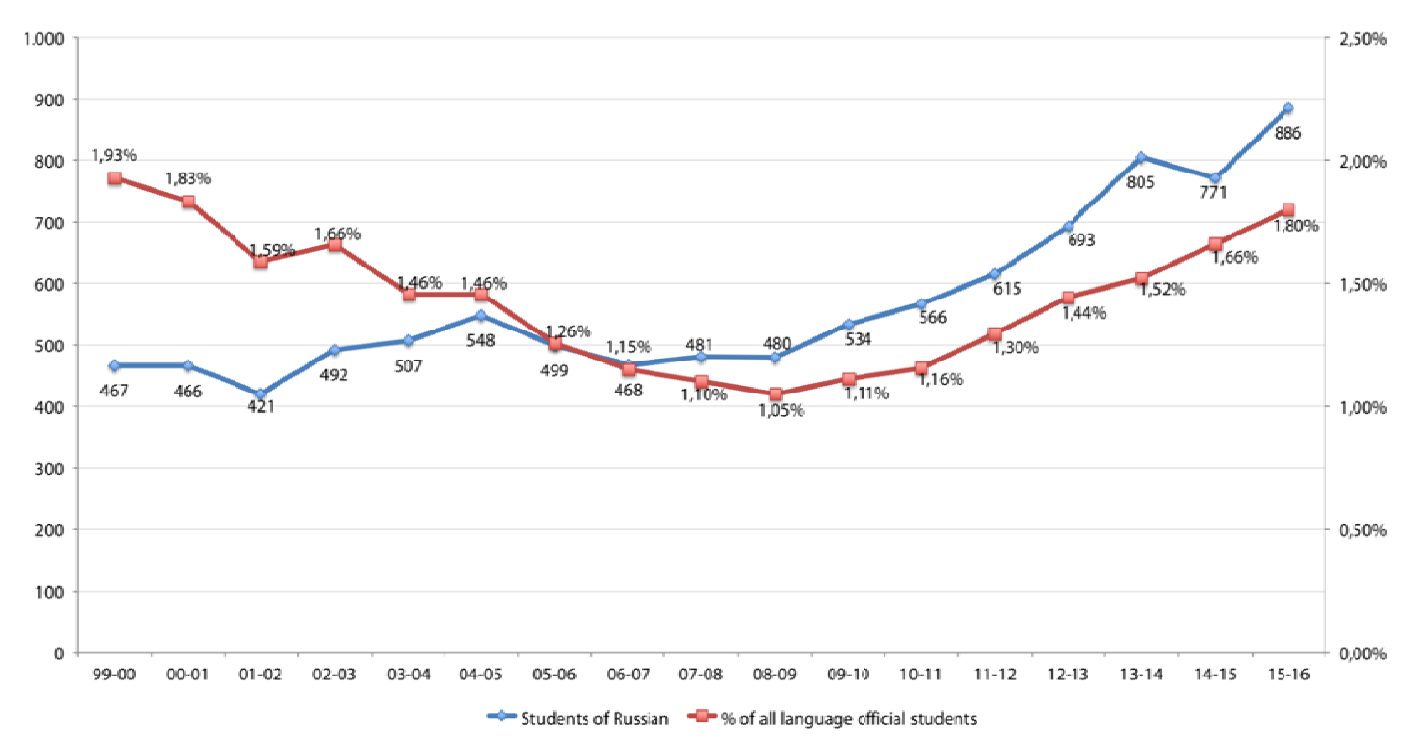

Figure 7. Number of learners of Russian in relation to overall number of language learners in Catalonia

\section{CONCLUSIONS}

The purpose of this paper was to examine the uses of Russian in Catalan tourism industry between 2014 and 2016. Based on ethnographic research over time, I highlighted in which particular contexts Russian is used in the local tourism industry and how this changed in the light of political and economic contexts that led to a considerable decrease of tourist visits of Russian speakers. While my data from interviews, questionnaires and within the linguistic landscapes of Barcelona and Salou show the continuing importance of the language. However, while Russian retained some of its commodity value, the interconnectedness of language commodification processes with global economics and (geo)politics make it impossible to foresee what role Russian will play in Catalonia in the (near) future. As Pavlenko (2017: 16) highlights, Russian is "a commodity that cannot be easily dissociated from the political identity of its putative speakers". This cognitive dissonance between high purchasing power of Russian visitors and negative attitudes towards Russia has exacerbated in the past few years and it remains to be seen whether Russian will remain a valuable resource in Catalan tourism industry.

(C) Miquel Cabal-Guarro, 2017

\section{REFERENCES}

Agència catalana de turisme (2015) Dossier de premsa 2014. Barcelona.

Appadurai, A. (1986) Introduction: commodities and the politics of value. In A. Appadurai (ed.) The social life of things. Oxford: Oxford University Press, 3-63.

Bourdieu, P. (1986) The Forms of Capital. In J. G. Richardson (ed.) Handbook of Theory of Research for the Sociology of Education. New York: Greenwood Press, 241-258. 
Cushman and Wakefield (2016) Main Streets across the world. London. Available at: http://www.cushmanwakefield.com [Retrieved: 11.01.2017].

Heller, M. (2010) The Commodification of Language. Annual Review of Anthropology, 39 (1), 101114.

Heller, M. and Duchêne, A. (2012) Pride and Profit. Changing Discourses of Language, Capital and Nation-State. In M. Heller and A. Duchêne (eds.) Language in Late Capitalism: Pride and Profit. London: Routledge, $1-21$.

Heller, M., Pujolar, J. and Duchêne, A. (2014) Linguistic commodification in tourism. Journal of Sociolinguistics, 18 (4), 539-566.

IDESCAT, 2015. Enquesta d'usos lingüístics de la població 2013. Barcelona. English version of the main facts available at: http://lengua.gencat.cat/web/content/documents/publicacions/altres/ arxius/EULP2013_angles.pdf [Retrieved: 18.12.2016].

Irvine, J. T. (1989). When Talk Isn't Cheap: Language and Political Economy. American Ethnologist, 16(2), 248-267.

Pavlenko, A. and Mullen, A. (2015) Why diachronicity matters in the study of linguistic landscapes. Linguistic Landscapes, 1, 1-2, 108-126.

Pavlenko, A. (2017) Russian-friendly: how Russian became a commodity in Europe and beyond. International Journal of Bilingual Education and Bilingualism, 50 (April), 1-19.

Shohamy, E and D. Gorter (eds.) 2008, Linguistic Landscape: Expanding the Scenery. London and New York: Routledge.

UNWTO (United Nations World Travel Organization), 2004. Annual Report 2015. Madrid. Available at: http://cf.cdn.unwto.org/sites/all/files/pdf/annual_report_2015_lr.pdf [Retrieved: 23.03.2017].

WEF (World Economic Forum), 2015. The Travel \& Tourism Competitiveness Report 2015. Geneva. Available at: http://www3.weforum.org/docs/TT15/WEF_Global_Travel\&Tourism_Report_ 2015.pdf [Retrieved: 23.03.2017].

\section{Article history:}

Received: 15 March 2017

Revised: 07 May 2017

Accepted: 01 June 2017

\section{For citation:}

Cabal-Guarro, M. (2017) Is Russian Decommodifying in Catalonia? Russian Journal of Linguistics, 21 (3), 605-619. doi 10.22363/2312-9182-2017-21-3-605-619.

\section{Bio Note:}

Miquel Cabal-Guarro, $\mathrm{PhD}$ in Linguistics at the University of Barcelona, Catalonia. He works as a literary translator and researcher in Sociolinguistics. Amongst his translations into Catalan, there are novels and plays of renowned authors as Dostoyevski, Tolstoy, Tsvetaeva, Dovlatov, Platonov or Chekhov. He is currently collaborating with the Research Centre for Sociolinguistics and Communication (CUSC) and the Group for the Study of Endangered Languages (GELA) at the University of Barcelona. Research interests: Sociolinguistics of the post-Soviet space, especially in Crimea and Ukraine, as well as the role of Russian in the post-Soviet countries. Contact information: e-mail: miquelcabal@ub.edu 
DOI: $10.22363 / 2312-9182-2017-21-3-605-619$

\title{
ЭКОНОМИЧЕСКАЯ ЗНАЧИМОСТЬ РУССКОГО ЯЗЫКА В КАТАЛОНИИ: ВЕКТОР РОСТА ИЛИ ПАДЕНИЯ?
}

\author{
Микел Кабал-Гуарро \\ Исследовательский центр социолингвистики и коммуникации (CUSC) \\ Университет Барселоны \\ 585 Gran Via de les Corts Catalanes, 08007 Barcelona, Spain
}

\begin{abstract}
Данные, собранные в ходе этнографического исследования, проведенного в 2014-16 гг. в туристических районах Каталонии, Испания, показывают, что в испанской индустрии туризма владение русским языком стало прибыльным товаром. Цель этой статьи - показать, где и как русский язык используется в сфере услуг, и проследить коммодификацию русского языка с течением времени. На фоне колебания числа русскоязычных туристов этот анализ будет способствовать лучшему пониманию процессов коммодификации и декоммодификации языка, а также отношений между более широкими политическими и экономическими контекстами и значимостью конкретных языков и говорящих на них людей.
\end{abstract}

Ключевые слова: русский язык, коммодификация, лингвистические ландшафты, туризм, Каталония, Испания

\section{История статьи:}

Дата принятия в редакцию: 15 марта 2017

Дата принятия в печать: 01 июня 2017

\section{Для цитирования:}

Cabal-Guarro, M. Is Russian Decommodifying in Catalonia? // Вестник Российского университета дружбы народов. Серия: Лингвистика. 2017. Т. 21. № 3. С. 605-619. doi 10.22363/2312-9182-2017-21-3-605-619.

\section{Сведения об авторе:}

Микел Кабал-Гуарро, кандидат филологических наук в Университете Барселоны, Каталония. Он работает литературным переводчиком и исследователем в области социолингвистики. Среди его переводов на каталанский язык есть романы и пьесы известных русских писателей, таких как Достоевский, Толстой, Цветаева, Довлатов, Платонов, Чехов. В настоящее время он сотрудничает с Исследовательским центром социолингвистики и коммуникации (CUSC) и Группой по изучению исчезающих языков (GELA) в университете Барселоны. Сфера научных интересов: социолингвистика постсоветского пространства, особенно в Крыму и Украине, а также роль русского языка в постсоветских странах. Контактная информащия: e-mail: miquelcabal@ub.edu. 